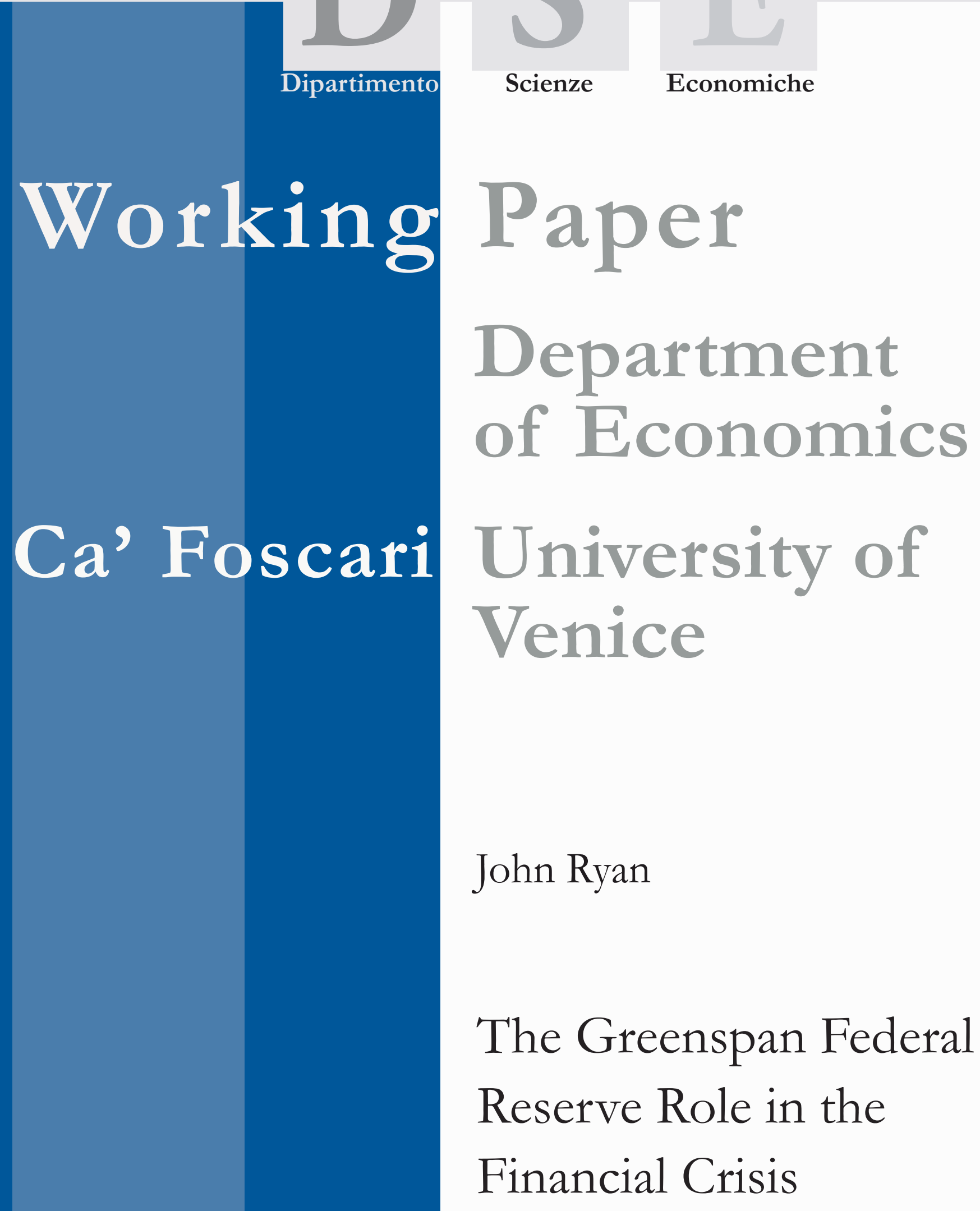




\title{
The Greenspan Federal Reserve Role in the Financial Crisis
}

\author{
John Ryan \\ Hult International Business School and CEPA
}

First Draft: February 2009

\begin{abstract}
The Federal Reserve System or the Fed is one of the most prestigious institutions in the world. Founded by the Federal Reserve Act in 1913, the Fed has the responsibility of setting the monetary policy of the U.S. The Fed's actions affect the money supply in the U.S. market which has a direct influence on interest rates, growth and inflation. To better understand the role of the Fed we will first describe its structure and organization. We will then see who is really behind the central bank's actions and who holds the reins of power inside the institution that plays the most important role in financial markets throughout the world. The monetary policy implemented by the Fed is closely monitored by major financial markets and institutions as it affects directly investments and security prices. We will explain clearly how the Fed conducts its monetary policy using three major tools to either decrease or increase money supply: open market operations, adjusting the discount rate and adjusting the reserve requirement ratio. We examine the main objectives of the Fed's monetary policies and how those objectives maintain a "conflict of interest" relationship. Finally we will examine the policies of the former chairman of the Fed Alan Greenspan (1987-2006) which contributed to the current crisis. We will also briefly assess the policy performance of Ben Bernanke.
\end{abstract}

\section{Keywords}

Federal Reserve, Monetary Policy, Alan Greenspan, Ben Bernanke, Wall Street

\section{JEL Codes}

E02, E44, E50, E51, E52, E58, E61, G18

\author{
Address for correspondence: \\ John Ryan \\ Flat 7,307 Upper Richmond Road, \\ London SW15 6SS \\ England \\ Phone: $(++44) 7951765549$ \\ e-mail:JMTRYAN@aol.com
}

This Working Paper is published under the auspices of the Department of Economics of the Ca' Foscari University of Venice. Opinions expressed herein are those of the authors and not those of the Department. The Working Paper series is designed to divulge preliminary or incomplete work, circulated to favour discussion and comments. Citation of this paper should consider its provisional character.

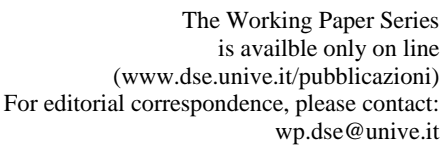

The Working Paper Serie

ce, please contact:
Department of Economics

Ca' Foscari University of Venice

Cannaregio 873, Fondamenta San Giobbe

30121 Venice Italy

Fax: ++39 0412349210 


\section{I - The Fed}

The Federal Reserve System, essentially the central bank of the United States and otherwise known as 'the Fed', was “...founded in 1913 to provide the nation with a safer, more flexible, and more stable monetary and financial system; over the years its role in banking and the economy has expanded.” ${ }^{1}$ The Fed has four principle aims:

1. “Conducting the nation's monetary policy by influencing the money and credit conditions in the economy in pursuit of full employment and stable prices.

2. Supervising and regulating banking institutions to ensure the safety and soundness of the nation's banking and financial system and to protect the credit rights of consumers. 3. Maintaining the stability of the financial system and containing systemic risk that may arise in financial markets.

4. Providing certain financial services to the U.S. government, to the public, to financial institutions, and to foreign official institutions, including playing a major role in operating the nation's payments system.,"2

Despite its creation in 1913, the Federal Reserve System did not solidify until 1935 (in the midst of the Great Depression), with the passing of the Banking Act that expanded the Fed's powers. The Federal Reserve System consists of twelve regions, each containing their own Federal Reserve Bank. A Board of Governors based in Washington D.C. manages the entire system, with each member serving a term of fourteen years. By appointment of the President and confirmation of Congress, the Federal Reserve Chairman is in charge of Fed operations. ${ }^{3}$ Most importantly, the U.S. Congress considers the central bank independent of the federal government, in that its decisions do not need legislative ratification. However, since Congress created the Federal Reserve, it could

\footnotetext{
1 “The Federal Reserve System: Purposes and Functions.” http://www.federalreserve.gov/pf/pf.htm p. 6

2 “The Federal Reserve System: Purposes and Functions.” p. 6

3 “The Federal Reserve System: Purposes and Functions.” p. 6
} 
theoretically eliminate it, and the appointment of the Chairman requires confirmation from Congress, guaranteeing the government some level of influence.

The Federal Reserve System has three primary tools to influence economics; the Federal Open Market Committee (FOMC), headed by the Chairman, is delegated to decide how and when these tools are implemented. The first tool of the Fed is the process of "open market operations"-or the buying and selling of United States securities (such as bonds) to influence the money supply and interest rates. The second tool is the power to set the required reserve ratio of commercial banking institutions, or the amount of liquid cash that banks must hold in relation to the amount of outstanding deposits. As its third tool, the Fed sets the discount rate, the interest rate at which these commercial banking institutions borrow money from regional Federal Banks in order to preserve the specific reserve ratio required by the Federal Reserve. ${ }^{4}$

These tools allow the Fed to influence a great deal of operations. The amount of reserves that a bank is required to hold directly affects the amount of money that a bank can loan out. By lowering the discount rate, banks will be inspired to borrow from the government because they will have a relatively smaller burden in repaying the Federal Bank. If a commercial bank has more funds, it is then more likely to give out loans to prospective homebuyers or small business owners, thus spurring investment, consumption, and production. An increase in overall interest rates will slow down both individual consumption and borrowing-people will be more likely to save money for their children's education or other future investments, and businesses will be less likely to borrow money because the interest on that loan will represent too much of a future liability.

\footnotetext{
4 “The Federal Reserve System: Purposes and Functions.” p. 10
} 


\section{II- Organization and Structure of the Federal Reserve System (Fed)}

\section{Historical Perspective}

To understand the structure of the Federal Reserve System, we need to understand first the characteristics of the U.S. politics at the time of its establishment in 1913. In fact why does one of the most prestigious institutions in the world have one of the most unusual structures?

The U.S. constitution in its checks and balances and its preservation of states rights mirrors clearly the fear of the founding fathers and the U.S. people at that time from a centralized power. And it was this fear of centralized power that was behind the hostility of Americans towards the establishment of a prominent symbol of centralization such as a central bank. In 1791 the first Bank of the United States was created to supervise the well-functioning of the banking system and to sustain a stable economy. It was terminated in 1811 because of the non-renewal of its charter by the congress. In 1816 the second Bank of the United States was established. It was also terminated in 1836 by a veto of President Andrew Jackson. ${ }^{5}$ During the late 1800’s and early 1900's many severe bank panics occurred in the American financial markets. This culminated in the 1907 panic which was a harsh crisis where many banks went bankrupt across the whole country. Accordingly, in 1913 the Federal Reserve Act was passed, creating the Federal Reserve System. It also defined 12 districts across the U.S. and a city in each district where a Federal Reserve district bank was to be founded.

\footnotetext{
${ }^{5}$ Note that this time the congress voted on its renewal.
} 


\section{Formal Structure of the Fed}

\section{a- Federal Reserve District Banks}

Deciding to create 12 district banks across the U.S. the American congress was clearly aiming to create a decentralized system making sure that all regions in the country were represented and participating in monetary policy issues. The 12 Federal Reserve districts and city location of the banks are shown in Figure 1.

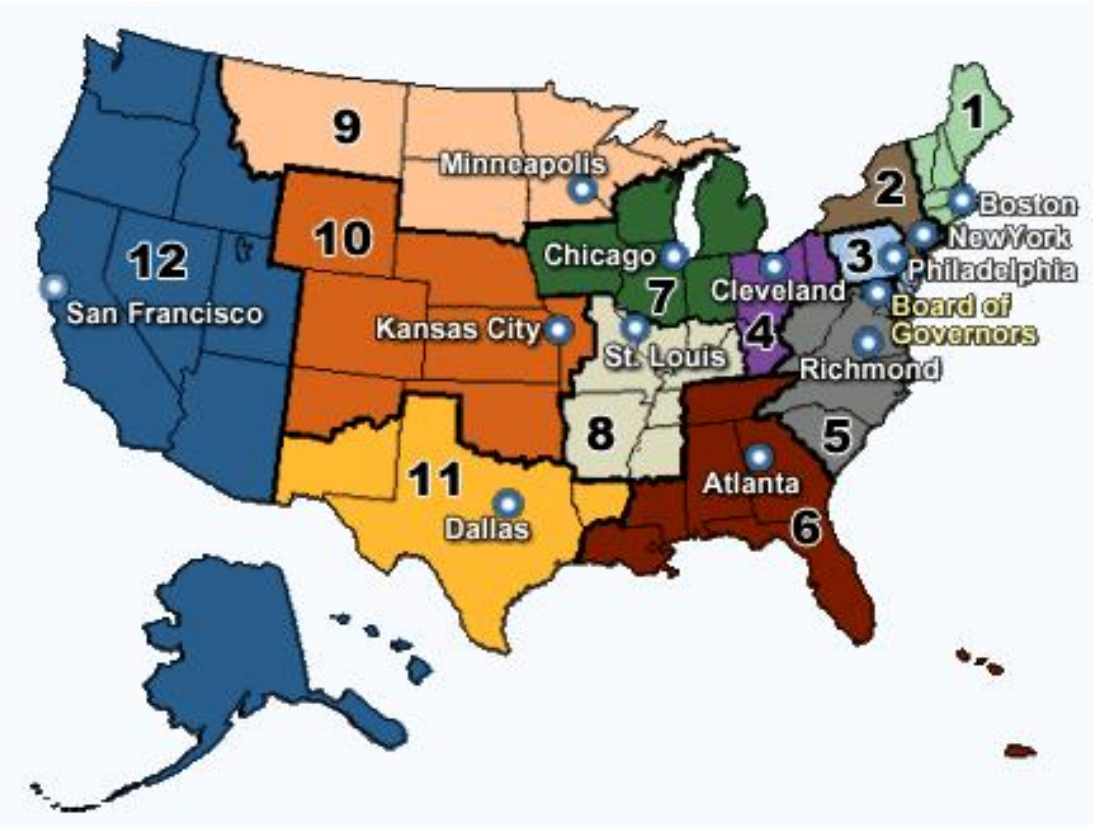

Figure 1: The twelve Federal Reserve District Banks ${ }^{6}$

\footnotetext{
${ }^{6}$ Source: www.dallasfed.org/fed.district.html
} 
The three largest Federal Reserve District Banks in terms of assets are those of New York, Chicago and San Francisco. ${ }^{7}$ Out of these three, it is the New York district bank that is the most important with nearly $25 \%$ of the assets of the Fed because many large banks are located in this district ${ }^{8}$. Each Federal Reserve Bank is privately and publicly owned at the same time. Commercial Banks of the district that become members of the Fed are required to purchase stock in their Federal Reserve District Bank. Those stocks are not traded in the secondary market and pay a maximum dividend of $6 \%$ annually as stated by the law. Each Fed district bank has nine directors. Member banks in each district elect six directors and the three others are appointed by the Board of Governors ${ }^{9}$. All nine directors appoint the president of their district bank; but the decision should be approved by the Board of Governors. The choice of the nine directors should reflect all categories of the American economy and public. In fact, of those nine directors, three are professional bankers, three others are businesspeople from all sectors of the economy ${ }^{10}$, and the final three represent the public interest. ${ }^{11}$

Functions of the 12 Federal Reserve Banks include the following ${ }^{12}$ :

- Check clearance

- Issuance of currency

- Withdrawal of damaged currency

- Evaluation of Bank mergers and expansion of activities

- Making discount loans to banks in their district

- Examination of bank holdings companies

- Data collection on economic and business conditions

- Research on Monetary policy

\footnotetext{
${ }^{7}$ Together they hold 50\% of the assets of the FED (Discount loans, securities and other holdings)

${ }^{8}$ Mishkin,F., Eakins,S., “Financial Markets \& Institutions”, $5^{\text {th }}$ edition, Pearson (2006), p155

${ }^{9}$ Note that some directors are elected but others are appointed.

${ }^{10}$ Note that sectors of the economy include industry, labour, agriculture and consumers.

${ }^{11}$ Note that those directors are not allowed to be employees or stockholders of banks. If they chose to do so, they need to resign.

${ }^{12}$ Mishkin,F., Eakins,S., “Financial Markets \& Institutions”, $5^{\text {th }}$ edition, Pearson (2006), p155
} 
The 12 Federal Reserve District Banks have the following powers ${ }^{13}$ :

- They establish the discount rates which are reviewed and determined by the Board of Governors

- They decide over discount loans to member or non-member banks

- They select one commercial banker from each bank's district to serve on the Federal Advisory Council.

- Five of the 12 bank presidents have a vote in the Federal Open Market Committee.(The president of the New York bank always has a vote in the FOMC; and the other four votes rotate annually among the remaining 11 presidents).

\section{b- Member Banks}

The national banks that are chartered by the Comptroller of the currency are required to be members of the Fed, but other banks that are chartered by their respective states are not. Before 1980 only member banks were required to keep deposits at the Federal Reserve Bank on which no interests were paid. So it was costly to be member of the Fed especially when interest rates rise. The direct effect of this was that more and more banks left the Fed. Today 35\% of all banks are members whereas in 1947 50\% were. This decline in Fed membership narrowed the Fed's control over the money supply and it was harder for it to carry out its monetary policy effectively. In 1980, after pressure from the Board of Governors on the congress, the Depository Institutions Deregulation and Monetary Control Act of 1980 were voted on. This Act stated that by 1987 all depository institutions are required to keep reserves as deposits at the Fed. Members and nonmember banks had from 1987 reserve requirements towards the Fed and were now equal on this point.

\footnotetext{
${ }^{13}$ Mishkin,F., Eakins,S., “Financial Markets \& Institutions”, $5^{\text {th }}$ edition, Pearson (2006), p156
} 


\section{c- Board of Governors}

The Board of Governors or the Federal Reserve Board is based in Washington D.C. It is made up by seven members appointed by the president of the United States. They serve a non-renewable term of 14 years $^{14}$. The intention behind this long-standing term is to limit political pressure on the governors so that they can build up monetary policies that will benefit the U.S. over the long-term. The terms are spread out so that one term expires every even-numbered year. For better representation of the American people and regions, governors should come from different Federal Reserve Districts. One of the seven board governors is selected by the U.S. president to be Chairman of the Federal Reserve; he serves a 4-year term which can be renewed. ${ }^{15}$ The board has two main duties:

1. Regulation of commercial banks

2. Controlling of the Monetary Policy

The first duty of the Board of Governors which is the regulation of commercial banks involves banks that are members of the Fed and bank holdings companies. It also supervises the action of the 12 Federal Reserve District banks which offer services to depository institutions and commercial banks in their district. In addition to that the board is responsible for the setting of margin requirements which is the "minimum amount of cash or eligible securities that must be paid with non-borrowed funds as spelled out by regulation”. 16

The second duty of the Board of Governors is the conduct of Monetary Policy. In fact the board has the power to revise reserve requirements imposed on depository institutions. It also controls the Discount rate by authorizing or not the changes in this rate set by the

\footnotetext{
${ }^{14}$ Note that a governor can resign before the expiry of his term and be reappointed by the president. An example of this is governor McChesney who served for 28 years.

${ }^{15}$ Paul Volcker served as chairman from 1979 to 1987. Alan Greenspan served from 1987 to 2006.

${ }^{16}$ Downes J, Jordan, E, “Dictionary of Finance and Investment Terms”, Barron's, $6{ }^{\text {th }}$ edition, (2003)
} 
Federal Reserve banks. This process is known as "review and determination” process. ${ }^{17}$. The seven members of the Board of Governors are also members of the Federal Open Market Committee (FOMC) and have equal votes. The FOMC consists of 12 members. Thus the board has the majority of the votes in this committee; and by that way controls largely a third tool of monetary policy which is the money supply determined by open market operations.

The Board of Governors plays also other minor roles. In fact the board has bank regulatory functions when approving mergers of banks and allowing new activities for bank holding companies. It also oversees the activities of foreign banks in the U.S. Moreover, the board has staff for conducting economic analysis and research. It also sets the salary of the U.S. president and all officers of Federal Reserve District banks and reviews each bank budget.

Finally, the chairman of the board advises the U.S. president on economic policy. He also testifies in front of the congress and is the Fed spokesman to the media ${ }^{18}$. The chairman or another governor can represent the U.S. on economic issues outside the country.

\section{d- Federal Open Market Committee (FOMC)}

The Federal Open Market Committee (FOMC) ${ }^{19}$ consists of 12 members: seven members of the board of governors and 5 presidents of district banks. The president of the New York district bank is a permanent member while the other four are determined among the 11 remaining presidents on a rotating basis. The seven other presidents of district banks attend the FOMC meeting, participate in the discussions, but have no voting rights. The chairman of the board of governors is also the chairman of the FOMC. The committee usually meets 8 times a year (every six weeks) and carries out open market operations to

\footnotetext{
${ }^{17}$ Mishkin,F., Eakins,S., “Financial Markets \& Institutions”, $5^{\text {th }}$ edition, Pearson (2006), p157

${ }^{18}$ Note that the information release from the Fed, directly after the FOMC meeting, began in 1994 to show more transparency and openness by the Fed as it was a very "secret” institution before.

${ }^{19}$ The FOMC is often referred to as the "Fed" in the press.
} 
control the money supply. The FOMC meeting takes place in Washington D.C. where the attendance consists of:

- The seven governors.

- The 12 reserve bank presidents.

- The secretary of the FOMC, the board's director of the Research and Statistics Division and his deputy.

- The directors of the Monetary Affairs and International Finance Divisions.

- The Directors of Research at each reserve district bank. (Sit around the side of the rooms and do not speak by tradition)

- Other senior board and reserve bank officials. (Sit around the side of the rooms and do not speak by tradition)

The FOMC meeting is divided into two major phases. The first phase is a presentation by the director of the Research and Statistics Division on the national economic forecast. He is then queried by the governors and reserve bank presidents. Then each bank president presents an overview of the economic situation in his district and the bank's view on the national economy. The governors do the same, except for the chairman.

The second phase deals extensively with monetary policy; where the board's director of the Monetary Affairs Division summarizes different scenarios of monetary policy actions. He is then queried by the governors and reserve bank presidents. Then it is the chairman's turn to give his view on the present situation of the economy and recommend a monetary policy action that should be applied. Now each FOMC member discusses his or her views on the proposed monetary policy. The discussion is summarized by the chairman who proposes a wording for the statement that is finally read by the FOMC secretary. The FOMC members vote. ${ }^{20}$

\footnotetext{
${ }^{20}$ Note that those votes may not be unanimous and are made public. The chairman's vote is usually on the winning side.
} 
The statement which contains the new decisions by the FOMC is then sent to the Trading Desk or the Open Market Desk at the New York Fed District bank. It is there that open market operations take place. After the FOMC meeting, new directives and directions of the monetary policy are directly announced to the public.

\section{e- Advisory Committees}

The Federal Advisory Council makes recommendations to the Fed about economic and banking issues. It is made up of members from the 12 Federal Reserve districts. They are elected each year by their respective board of directors of the district banks. Washington D.C. is the headquarters for the meeting that takes place 4 times a year.

The Consumer Advisory Council consists of 30 members and discusses consumer issues. The Thrift Institutions Advisory Council consists of representatives of saving banks, savings and loan associations, and credit unions.

\section{Informal Power Structure of the Federal Reserve System}

When the U.S. Congress voted in the legislation of the Federal Reserve Act of 1913, it had considered a highly decentralized system designed to work as 12 separate, cooperating central banks. The Federal Reserve Act also enabled the Fed to control only one monetary policy tool which is the discount loans to member banks. At that time open market operations were not widely used and the percentage of reserve requirement was set by the law.

Moreover, the discount tool was to be controlled by both the Board of Governors ${ }^{21}$ and the 12 district banks. But the ability of the Board to review the discount rate gave it more power over the district banks. Today it is mainly the Fed that set this policy tool.

\footnotetext{
${ }^{21}$ At that time the Board of Governors was known as Federal Reserve Board.
} 
It is after the 1929 crash of Wall Street that legislation by the Congress began to give more centralized power to the Board of Governors. In fact the Banking Act of 1933 gave the FOMC the power to determine open market operations. The Banking Act of 1935 gave the Board the majority of votes in the FOMC. We can see now that the Board of Governors has gained control over another monetary policy tool which is the open market operations. In addition to that the Banking Act of 1935 granted the board the authority to change reserve requirements; thus giving it the power to control the third monetary policy tool.

The Board of Governors sets also the salary of the President of each Federal District Bank and reviews the budget of those district banks. This direct influence (controlling the purse strings) by the board over the 12 federal district banks is clearly shown when the Board suggests a name for the presidency of a federal district bank and this suggestion is usually taken into consideration by the directors of the bank; although they have the right to choose a president by themselves with only the approval of the Board.

In addition to this, the "owners" of the Federal Reserve Bank which are the member banks have almost no power in the decision-making process of the Fed. Although they own stock in the Fed, they only get paid $6 \%$ dividend per year which is set by the law regardless of how much the Fed makes in profits. The Fed can also use those stocks in which way it finds it useful without the consent of the member banks. Of course this is not the case in private corporations where shareholders own stocks in the company.

Not to mention that from the six directors (A and B categories) that are supposed to be elected by member banks, only one represents them truly. And even this only director is often suggested by the Fed.

The three Advisory Councils, as their names imply, have no authority at all over the Federal Reserve decision-making process.

Finally, we can clearly see that the Federal Reserve System as it evolved can be considered as a powerful Central Bank, headquartered in Washington D.C. with branches 
in 12 American cities. Inside the Fed, it is the Board of Governors that controls nearly everything. It is the Chairman of the Board that exercises major controls over this body, although this is not stated by the law. In fact, it is the chairman that is the spokesman of the Fed in front of the Congress; and it is him who negotiates with the President of the United States about economical issues. He also has the authority to set the agenda of the Board and the FOMC meetings, gaining control of what is going to be discussed in this meeting. And during those meetings, it is him who speaks first about monetary policy; thus gaining more influence on the decision-making process. He also supervises the team of economists and advisers that are in the board staff.

The following figure (Figure 2) shows the formal structure of the Fed with its different components and the distribution of monetary policy responsibilities. 


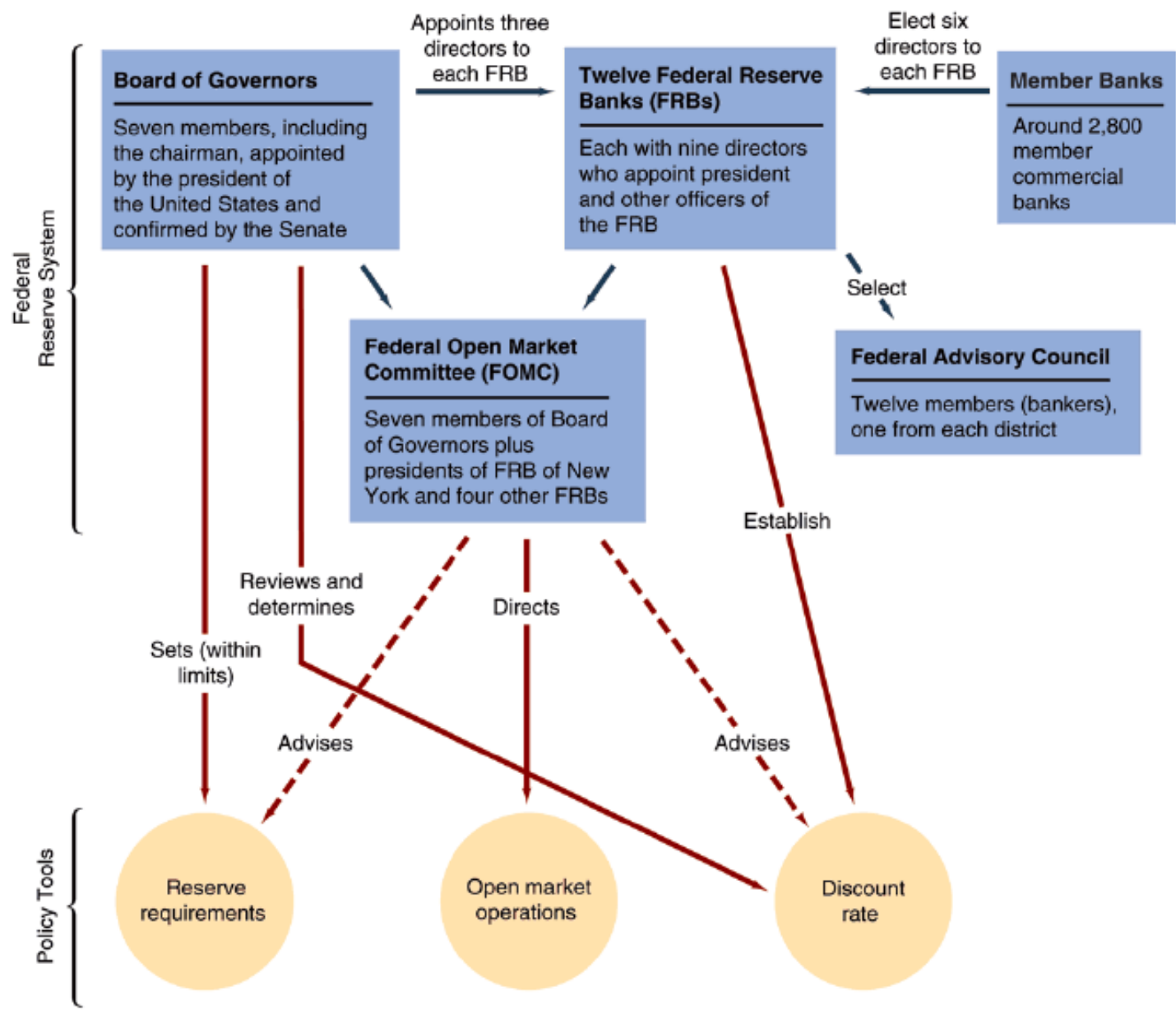

Figure 2: Formal Structure and Allocation of Policy Tools in the $\mathrm{Fed}^{22}$

The above Figure 2 can be drawn in a different way to better illustrate the power structure of the Fed that is centralized in the person of the chairman. Of course this structure is an informal one that does not reflect what is written in black and white in the Federal Reserve Act. Note that Figure 3 below does not include monetary policy tools.

${ }^{22}$ Mishkin,F., Eakins,S., “Financial Markets \& Institutions”, 5 ${ }^{\text {th }}$ edition, Pearson (2006), p153 


\section{Federal Reserve System}

\section{Chairman}

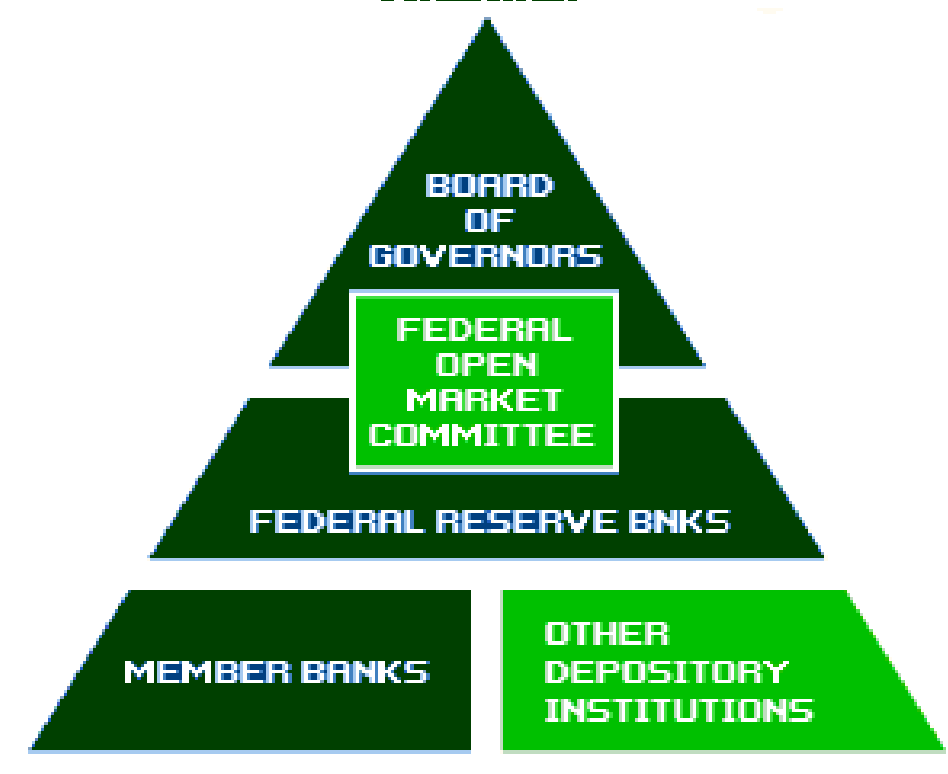

\section{RMERICAN PEOPLE}

Figure 3: Pyramid Hierarchy of the power structure in the Fed

\section{III- Monetary Policy}

The conduct of monetary policy has a direct effect on the performance of the economy because it has a major impact on money supply and interest rates. The relationship between money supply and economic conditions is a vast subject that cannot be explained in this paper. But we will explain how the Fed uses three monetary policy tools to control money supply by either decreasing or increasing it. 
The three main monetary policy tools are the following:

- Open Market Operation

- Adjustments in the discount rate

- Reserve Requirement

\section{Monetary Policy Tools}

\section{a- Open Market Operation}

Open market operation is "the Fed's purchase or sale of bonds in the open market"23. When the FOMC meets eight times a year, it determines the target money supply level according to the present economic situation and future forecasts. This target money supply level is specified in the form of a range between a minimum desired limit and a maximum desired limit over the next coming months; rather than one definite target. (Ex: $3 \%<$ money supply growth $<5 \%$ ). Then the FOMC's decisions on the target money supply level are sent to the trading desk at the New York Federal Reserve District Bank through a statement called the "policy directive" 24 . It is this trading desk that carries out the selling or buying of government securities. Even though it receives policy directives eight times a year from the FOMC, the trading desk constantly uses open market operations in order to keep the money supply level within the specified target range. When the Fed purchases securities through government securities dealers, "the account balances of the dealers are credited with this amount”25. Thus the total amount of funds at the dealer's banks increases by the dollar amount of securities purchased by the Fed. This will permit an increase in the money supply. Note that this could not happen if a particular investor would have purchased those government securities because the Fed's purchase results in the creation of new additional funds outside the circle of banks deposits, giving banks the ability to make new loans and create new deposits. An investor purchase would have only resulted in a change of account balances among commercial

\footnotetext{
${ }^{23}$ Mishkin,F., Eakins,S., “Financial Markets \& Institutions”, $5^{\text {th }}$ edition, Pearson (2006), p177

${ }^{24}$ Madura J, "Financial Markets \& Institutions"; $6^{\text {th }}$ Edition, South-Western Publishing (2000),p80

${ }^{25}$ Madura J, “Financial Markets \& Institutions”; $6{ }^{\text {th }}$ Edition, South-Western Publishing (2000).p80
} 
banks themselves. Finally, an open market purchase leads to an increase of deposits in commercial banks accounts and hence to a growth of the money supply or the monetary base. On the contrary, an open market sale leads to a reduction of deposits and reserves in commercial banks accounts and hence a decline in the money supply. But how could this control of money supply affect interest rates in the market and by that way the economy in general?

\section{b. Adjustments in the discount rate}

The Federal Reserve System implements monetary policy largely by targeting the federal funds rate. This is the rate that banks charge each other for overnight loans of federal funds, which are the reserves held by banks at the Fed. This rate is actually determined by the market and is not explicitly mandated by the Fed. The Fed therefore tries to align the effective federal funds rate with the targeted rate by adding or subtracting from the money supply through open market operations. The Federal Reserve System also directly sets the "discount rate", which is the interest rate for "discount window lending", overnight loans that member banks borrow directly from the Fed. This rate is generally set at a rate close to 100 points above the target federal funds rate. The idea is to encourage banks to seek alternative funding before using the "discount rate" option. ${ }^{26}$ The equivalent operation by the European Central Bank is referred to as the "marginal lending facility." 27

Both of these rates influence the prime rate which is usually about 3 percentage points higher than the federal funds rate. Lower interest rates stimulate economic activity by lowering the cost of borrowing, making it easier for consumers and businesses to buy and build, but at the cost of promoting the expansion of the money supply and thus greater inflation. Higher interest rates may slow the economy by increasing the cost of borrowing. The Federal Reserve System usually adjusts the federal funds rate by $0.25 \%$ or $0.50 \%$ at a time.

\footnotetext{
${ }^{26}$ Federal Reserve Bank San Francisco( 2004)

27 Patricia S. Pollard, February 2003). "A Look inside Two Central Banks: The European Central Bank and The Federal Reserve". Review (magazine) (St. Louis, Missouri: Federal Reserve Bank of St. Louis) 85 (2): 11-30.
} 
The Federal Reserve System might also attempt to use open market operations to change long-term interest rates, but its "buying power" on the market is significantly smaller than that of private institutions. The Fed can also attempt to "jawbone" the markets into moving towards the Fed's desired rates, but this is not always effective.

\section{C-Reserve Requirements}

Reserve requirements have long been a part of U.S. banking history. Depository institutions maintain a fraction of certain liabilities in reserve in specified assets. The Federal Reserve can adjust reserve requirements by changing required reserve ratios, the liabilities to which the ratios apply, or both. Changes in reserve requirements can have profound effects on the money stock and on the cost to banks of extending credit and are also costly to administer; therefore, reserve requirements are not adjusted frequently. Nonetheless, reserve requirements play a useful role in the conduct of open market operations by helping to ensure a predictable demand for Federal Reserve balances and thus enhancing the Federal Reserve's control over the federal funds rate.

Requiring depository institutions to hold a certain fraction of their deposits in reserve, either as cash in their vaults or as non-interest-bearing balances at the Federal Reserve does impose a cost on the private sector. The cost is equal to the amount of foregone interest on these funds-or at least on the portion of these funds that depository institutions hold only because of legal requirements and not to meet their customers' needs.

The burden of reserve requirements is structured to bear generally less heavily on smaller institutions. At every depository institution, a certain amount of reserve liabilities is exempt from reserve requirements, and a relatively low required reserve ratio is applied to reserve liabilities up to a specific level. The amounts of reserve liabilities exempt from reserve requirements and subject to the low required reserve ratio are adjusted annually to reflect growth in the banking system. 
Changes in reserve requirements can affect the money stock, by altering the volume of deposits that can be supported by a given level of reserves, and bank funding costs. Unless it is accompanied by an increase in the supply of Federal Reserve balances, an increase in reserve requirements (through an increase in the required reserve ratio, for example) reduces excess reserves, induces a contraction in bank credit and deposit levels, and raises interest rates. It also pushes up bank funding costs by increasing the amount of non-interest-bearing assets that must be held in reserve. Conversely, a decrease in reserve requirements, unless accompanied by a reduction in Federal Reserve balances, initially leaves depository institutions with excess reserves, which can encourage an expansion of bank credit and deposit levels and reduce interest rates.

\section{d- Comparison of the Monetary Policy tools}

If we want to make a comparison of the three monetary policy tools that the Fed uses, we can say that the Fed uses mostly open market operations. In fact open market operations can be used without divulgating the Fed's intentions. By that way they can be used continuously over time. Also the Fed has full control over the volume of the operations, which explains their flexibility and preciseness. They are also very easily reversed and can be implemented quickly (No administrative delays). Moreover, the discount rate will affect money supply only if banks respond to it; and loans from the discount window are usually for short term; thus the adjustment made by using the discount rate tool is temporary. The discount window is also the tool by which the Fed play its role of lender of last resort; which explains why the Fed is very careful when using this tool and does not use it frequently. It also embarrasses banks in their loan able funds policy decisionmaking. The power of the Federal Reserve sets the required reserve ratio of commercial banking institutions, or the amount of liquid cash that banks must hold in relation to the amount of outstanding deposits is also an important policy tool. 


\section{Goals of Monetary Policy}

The tools of Monetary Policy that we discussed above have six economic goals:
1. High Employment
2. Economic Growth
3. Price Stability
4. Interest-rate Stability
5. Stability of Financial Markets
6. Stability of Foreign Exchange Markets

We take a brief look at only two of those goals which are high employment and price stability. If the economy is weak and the unemployment rate is high, the Fed may desire to increase the level of spending and investments to boost the economy (See Figure 4). As discussed in part A of section III; it would do so by purchasing treasury securities using open market operations which result in the increase in the money supply and a decrease in the level of interest. By that way, an increase in money supply of loan able funds with low interest rates will cause an increase in business investments and spending. This will result in offer for jobs thus yielding a high employment rate.

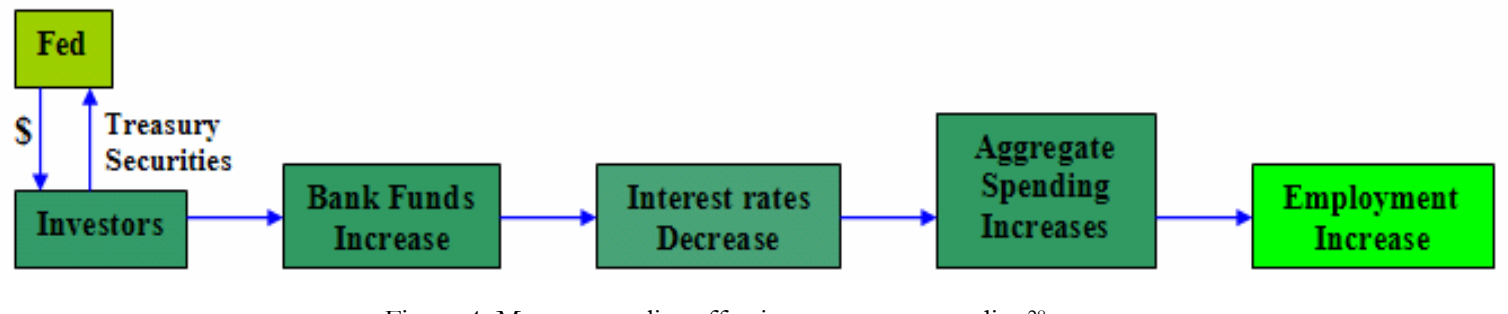

Figure 4: Monetary policy affecting aggregate spending 28

\footnotetext{
${ }^{28}$ Madura J, “Financial Markets \& Institutions”; 6 ${ }^{\text {th }}$ Edition, South-Western Publishing (2000), p98
} 
If the economy suffers from excessive inflation ${ }^{29}$, the Fed may want to reduce aggregate spending by selling treasury securities using open market operations causing a downward shift in the money supply and an increase in the level of interest rates. By that way, scarce money and higher interest rates will increase the cost of financing new business projects and thus decrease the level of investments and consumer spending and attenuate inflationary pressure (See Figure 5).

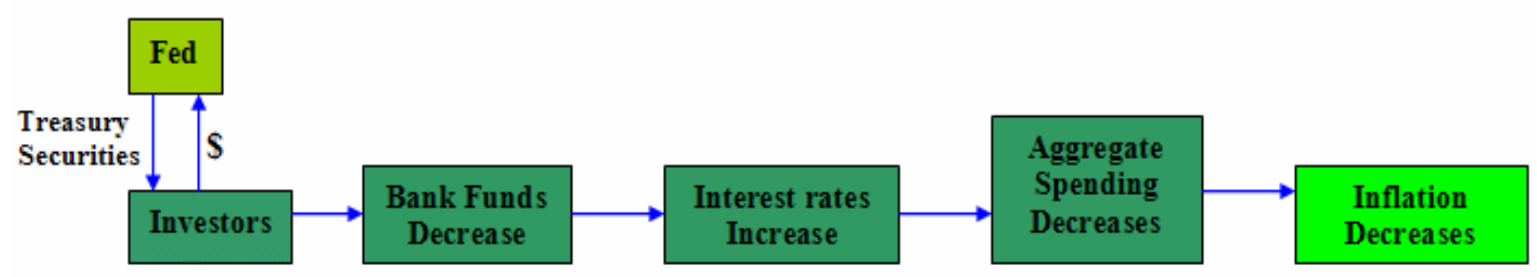

Figure 5: Monetary Policy affecting Inflationary Pressure ${ }^{30}$

Ideally the Fed would like to maintain a low inflation rate with a low unemployment rate. But given that a simulative monetary policy reduces unemployment rate and restrictive monetary policy reduces inflation, both rates maintain a negative correlation as they move in opposite ways. This is the reason why the Fed may not be able to adjust both rates together ${ }^{31}$. This negative correlation is known as the "Phillips Curve"32 and is shown in the following Graph 1.

\footnotetext{
${ }^{29}$ Inflation is "the rise in price of goods and services, as happens when spending increases relative to supply of goods on the market”; Downes J, Jordan, E, Dictionary of Finance and Investment Terms, Barron's, $6^{\text {th }}$ edition (2003).

${ }^{30}$ Madura J, “Financial Markets \& Institutions”; 6 ${ }^{\text {th }}$ Edition, South-Western Publishing (2000), p98

${ }^{31}$ Note that Employment rate, economic growth (measured by the GDP), interest rate stability and financial market stability maintain a positive correlation.

${ }^{32}$ Madura J, “Financial Markets \& Institutions”; 6 ${ }^{\text {th }}$ Edition, South-Western Publishing (2000), p 102
} 


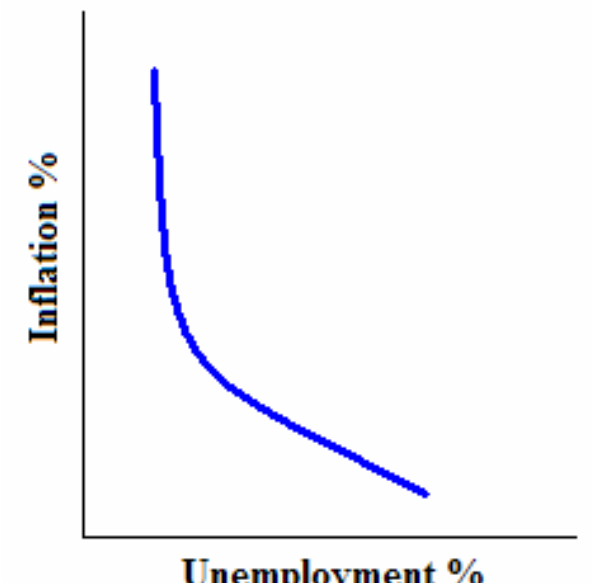

Graph 1: Negative Relationship between inflation and unemployment rates ${ }^{33}$

But does low inflation always mean high unemployment? In the next part of this paper we are going to see how the former Chairman of the Board of Governors of the Fed, Alan Greenspan seemed to be able to maintain good growth with low inflation for almost ten years $^{34}$.

\section{IV- Greenspan's Federal Reserve and the United States Economy}

The Federal Reserve can first increase the nation's overall money supply via the purchase of government bonds and securities from non-American government holders. The increased demand for bonds drives up their price and makes them appear less attractive to potential buyers, and individuals have an immediate boost to their liquid cash flow. Assuming that the overall demand for liquid funds remains the same, interest rates on bonds fall — the purchaser of a bond will receive less profit in the future. For instance, if IBM sells a bond at $\$ 100,000$ and promises to repay it in one year at $\$ 110,000$, then the interest gained is $\$ 10,000$ or $10 \%$; however if the price of the bond increases to $\$ 105,000$, then the interest gain falls to $\$ 5,000$, or $4.8 \%$. A drop in interest rates on bonds will

\footnotetext{
${ }^{33}$ Madura J, “Financial Markets \& Institutions”; 6 ${ }^{\text {th }}$ Edition, South-Western Publishing (2000), p103

${ }^{34}$ Valdez. S, “An introduction to Global Financial Markets”, $4^{\text {th }}$ edition, Palgrave, 2003 p58
} 
affect all national interest rates and drive them down. With the increased cash flow in consumer hands, spending will increase, as will investment because of the low interest payments on loans. Aggregate expenditure (total spending + total investment spending+ total government spending + net exports) thus increases, which, in the Keynesian model, leads to an increase in national GDP. ${ }^{35}$

On the other hand, the Fed can also slow down the economy by a reverse operation. Selling bonds on the open market first increases the overall public money supply and drives the prices of bonds down. The overall decrease in interest rates will inspire less consumption, for both consumers and businesses, and more savings. Businesses will borrow less because of high interest rates on loans, thus decreasing investment spending (e.g. for new facilities). If aggregate expenditure decreases, again according to the Keynesian model, national GDP will decrease.

While macroeconomic theory explains how interest rates spur or deflate the overall economy, interest rates have many practical microeconomic implications as well. The average consumer must be aware of how interest rates affect everyday life. Interest rates will help determine how much a person is willing to save, or spend, at a given time. If interest rates are high, one has greater incentive to store money in savings accounts because of the greater future payout on that money. Conversely, if interest rates fall, people have incentive to spend. Harking back to the basic definition of an interest rate, consumers will figure that the value of their dollar is higher now then in the future with a low interest rate (also, one must take inflation into account-low interest plus relatively higher inflation rates will devalue one's holdings even further). Spending power is generally good, because it gives consumers more choice and flexibility. If production goes up, people have incentive to buy stock in companies and watch their profits rise as overall GDP increases.

\footnotetext{
${ }^{35}$ Hall, Robert and Marc Lieberman. Economics: Principles and Applications. $3^{\text {rd }}$ Ed. Southwestern Publishing Company, New York, 2004.
} 
If interest rates are too low, people will borrow excessively, saddling themselves with increased debt for the future. For example, in an age where competition is increasing for fewer available jobs, higher education’s importance increases exponentially. To pay for the rising costs of a college education or post-graduate professional training, students and parents alike must take out large loans. Additionally, the prevalence of credit cards in the United States creates another avenue of debt creation — especially when people apply for credit cards in times of low interest. Even if people do not fall into debt, they still spend excessively because of the decreased benefits of saving, and consequently handicap themselves for retirement because of a meagre savings account or weak investments.

Monetary theory and the practice of central banking have failed to keep up with key developments in the financial systems of advanced market economies, and as a result of this; many central banks were to varying degrees ill-prepared for the financial crisis that erupted on August 9, 2007.

\section{The Federal Reserve's Reaction to 9/11}

The terrorist attacks of September $11^{\text {th }}, 2001$ on New York City and Washington D.C. were immediately detrimental to the U.S. economy. For example, when the New York Stock Exchange reopened on September $17^{\text {th }}$, the market fell 684.81 points, and by September $21^{\text {st }}$ had fallen to a level of $8,235.81$, compared to 9,605.51 a mere eleven days earlier on September $10^{\text {th }} \cdot{ }^{36}$ In New York City alone, physical, economic, and psychological damage estimates range into the hundreds of billions. The tragic loss of life left an indelible mark on American society, and the new psychological vulnerability of the nation's financial heart left consumers and producers alike uncertain of both the near and long term future. The “[American] economy’s success is tied to confidence," ${ }^{37}$ so consequently the Federal Reserve acted to eliminate uncertainty and create a new sense of confidence in the economy's psyche.

\footnotetext{
${ }^{36}$ Petruno, Tom. "Right Response to September 11 $1^{\text {th }}$ Remains Unclear.” LA Times. September 8, 2002.

37 Eisenberg, David. “Greenspans’s Deficits.” Time Magazine May 2, 2005. p. 44
} 
In the days following the terrorist attacks, the Federal Reserve injected $\$ 45$ billion in emergency funds into the economy. ${ }^{38}$ The logic behind this was to counteract the natural fear of spending consumers and businesses would exhibit after a destructive shock to the economy. For example, despite "patriotic buying" the stock market still plummeted as investors sold on airlines, New York based corporations, and other firms affected by the attacks, as evidenced above. As confidence decreased, Greenspan and the Fed decided to slash already falling interest rates. Before the terrorist attacks, the Fed had already cut interest rates seven times during 2001 in response to the earlier bursting of the Internet bubble and various other factors. On October $3^{\text {rd }}$, the Fed cut benchmark interest rates one-half percent for the second time since the attack, down to a level of $2.5 \%$, the lowest since 1962; the discount rate for banks also fell one-half percent to 2\%. ${ }^{39}$ By December $12^{\text {th }}$, the Fed cut the rates yet again to a level of $1.75 \%$, for a grand total of eleven cuts and a 4.75 point drop in interest rates for the entire year. ${ }^{40}$ These moves were "intended to reduce borrowing costs across the economy, helping to stimulate more economic activity among consumers and businesses,” and banks responded by cutting their lending rates at the same rate as the Fed did with each respective cut. ${ }^{41}$

The official recession of the American economy had actually began in March 2001 and lasted only one quarter — the fourth quarter of 2001 (after the terrorist attacks) actually displayed a $1.4 \%$ growth rate. ${ }^{42}$ Clearly, the dramatic decrease of interest rates did serve to inspire spending in a time of confusion, and also allowed Congress and the President to agree on a federal recovery package for the future. Indeed, by early 2002 experts heralded the onset of economic recovery. However, interest rates continued to plummet up through 2004-down to an absolute low of 1\%. While this is a tactic meant to keep

\footnotetext{
38 Anonymous. “A Tribute to an Unlikely Hero of 9/11.” Chicago Defender. April 18, 2002. p. 9

39 Stevenson, Richard. "Fed Cuts Its Benchmark Rate to 2.5\%, Hitting 39-Year Low.” New York Times. October 3, 2001. A1

40 Stevenson, Richard. "With the Economy Still Fragile the Fed Again Cuts Rates.” NewYork Times. December 12, 2001.

41 Stevenson, Richard. “With the Economy Still Fragile the Fed Again Cuts Rates.” NewYork Times. December 12, 2001.

42 Stevenson, Richard. “Fed Chief Sees Decline Over; House Passes Recovery Bill.” New York Times. March 8, 2002.
} 
spending up, there are negatives worth mentioning. Savings accounts, especially for retirees and baby boomers, returned very little. Consumers accumulated a high public debt on credit cards and mortgages, and the federal government became more reliant on foreign capital because of a growing trade and budget deficit. Only in late 2004 did the Fed begin to raise interest rates again, up to $2.25 \%$ by the end of that year. ${ }^{43}$ Raising interest rates increases savings returns but also premiums on mortgage, loan, and credit payments.

\section{The Alan Greenspan Era}

According to ABC News, in 1998 unemployment in the U.S. reached a 24-year low, inflation hit an 11-year low and consumer confidence was the highest it had been in 30 years. ${ }^{44}$ In fact during the 18-year mandate of Greenspan (1987-2006) at the head of the Fed, the U.S. benefited from a low inflation and suffered only two recessions. In fact inflation had not exceeded 5\% since 1991. The inflation percentages between 1984 and 2004 are given in the Graph 2 below.

United States Inflation (1984-2004)

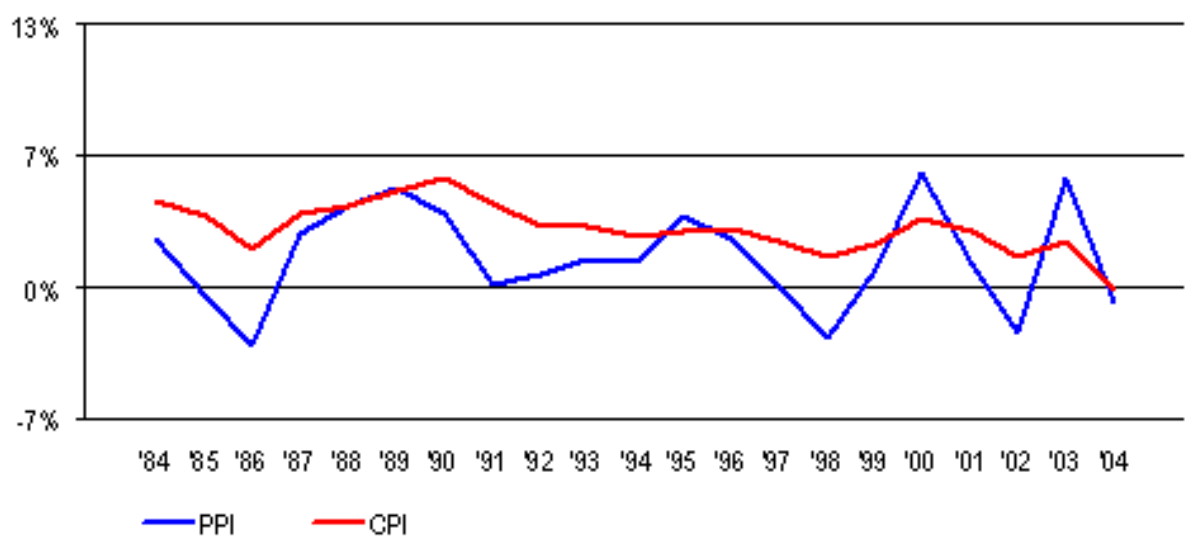

Graph 2: U.S inflation rates from 1987 to $2004^{45}$

\footnotetext{
43 “Interest Rates and Deficits.” The New York Times. Late edition. December 18, 2004,

${ }^{44}$ http://abcnews.go.com

${ }^{45}$ U.S Bureau of Labor Statistics, 2005
} 
Greenspan has managed to keep inflation low despite the stock market crash of 1987, several international crisis in the 1990s, a three-year bear market after the burst of the Dotcom bubble in 2000 and a terrorist attack on the world trade centers in New York in September $2001^{46}$. According to Martin Wolf, associate editor and chief economics commentator at the Financial Times, Greenspan "has become an almost legendary figure”. And that is because Greenspan succeeded in keeping inflation low when it had broken out all over the world. He also did so after succeeding the successful Paul Volcker who, before Greenspan, crushed inflation too. According to Martin Wolf other reasons also helped the Chairman of the Board of Governors in keeping inflation low with a stable growth: "The monetarist counter revolution, the pain caused by the inflationary excesses of the 1970s, globalization and the weakening of trade union power”. Wolf also made a comparison between Greenspan and the "father of Macroeconomics" John Maynard Keynes and asserted that both trust their own judgment and that both believe in "discretionary policymaking" and in the "wisdom of managing the long run by treating it as a series of short runs".

In the Jackson Hole 2005 symposium, Greenspan stated that his own approach to monetary policy was the following: "Maximum sustainable economic growth...with price stability pursued as necessary condition to promote that goal" ${ }^{\text {"47 }}$. In fact, to Martin Wolf, Greenspan’s focus on “maximum growth” along with his will to discover the “economy’s speed limit” by trial and error is also one of the reasons behind his success. Moreover, Wolf asserted that Alan Greenspan rejects “monetary targeting” because the relationship between money and spending broke up in the 1980’s and early 1990’s.

In 1996, the Fed Chairman warned of "Irrational Exuberance" and the idea of bubbles in the economy. Greenspan argued that it is impossible to know whether a bubble is occurring and that the right solution resides in a flexible economy. ${ }^{48}$

\footnotetext{
${ }^{46}$ Martin Wolf, associate editor and chief economics commentator at the Financial Times; “The Lessons and challenges for Greenspan’s Fed replacement”, FT Wednesday October 192005.

${ }^{47}$ www.federalreserve.gov

${ }^{48}$ Martin Wolf, associate editor and chief economics commentator at the Financial Times; “The Lessons and challenges for Greenspan’s Fed replacement”, FT Wednesday October 192005.
} 
A concern about Greenspan's approach to asset price bubbles is that the Fed was indifferent when prices were going up and intervened in an aggressive way when they were falling. According to Wolf, this policy encouraged investors to take excessive risks. He asserted that Greenspan or the Fed should have warned people of the risks they incur in excessive speculation, "rather than act as a cheerleader for U.S. productivity". In fact during the Dotcom bubble, Greenspan believed that increasing share prices was a sign of confidence in the growth of American corporations. ${ }^{49}$

Finally, according to Martin Wolf, three lessons should be drawn from the Greenspan era: The first is that it is hard for a central bank, especially the Fed as it is the most important of all, to decide on its monetary policy as it is hard to have a clear understanding of what's clearly going on in an economy, especially in asset prices. ${ }^{50}$ In my opinion, this has been clearly demonstrated during the excessive speculation of investors from 1996 to 2000 when no one believed that asset prices were overpriced and did not reflect at all their intrinsic values.

The second is that "giving so much discretion to an institution dominated by one person is risky”. In fact it is not until 1994 that the Fed moved towards more transparency and openness to the public. It is in 1994 that it began to reveal the FOMC directives after each FOMC meeting. It is also not until 1999, that it began to announce the "bias" toward which monetary policy was likely to go. Furthermore, it is not until 2002 that the Fed began to report to the press the vote on the federal funds rate target during the FOMC meetings.

\footnotetext{
${ }^{49}$ Valdez. S, “An introduction to Global Financial Markets”, $4^{\text {th }}$ edition, Palgrave, 2003:191

${ }^{50}$ Martin Wolf, associate editor and chief economics commentator at the Financial Times; "The Lessons and challenges for Greenspan’s Fed replacement”, FT Wednesday October 192005.
} 
Finally it is not until 2004 that the Fed began to release the minutes of the FOMC meeting after 3 weeks while it was 6 weeks before that date ${ }^{51}$. Even today the Fed is not fully transparent as it does not publish its forecast of the economy nor its target inflation rate as other central banks do ${ }^{52}$.

\section{Greenspan's Legacy}

Clearly, the U.S. economy relies a great deal on the movements of interest rates. The Federal Reserve, responsible for the manipulation of national interest rates, must analyze the current state of the economy and make adjustments that will lead to stable growth and consumer confidence in the nation's financial health. However, as the post 9/11 actions of the Fed show, excessive low interest can fuel too much spending, high consumer debt, low savings, and now combined with a declining dollar and the sub-prime crisis, have a serious consequence-namely stagflation. ${ }^{53}$ Factors indicating decline include high oil prices, rising healthcare costs, lingering fears of terrorism, and an increasing government debt that leaves too much of America's fate in foreign hands. ${ }^{54}$

Overall, the Federal Reserve did a good job of sustaining the U.S. economy after 9/11. Indeed, the purpose of the Federal Reserve is not necessarily to prevent cyclical downturns, but to shield the U.S. economy from sinking too far into the depths of cycles or, conversely, overheating to the point of excessive inflation. The Federal Reserve can also not be blamed for the escalating trade deficit that the federal government accrues by pursuing foreign military operations - it simply must take that into account when finetuning the economy. Perhaps more important than measured steps to preserve the U.S. economy would be to end the growing deficits and create a sense of balance in budgetary and trade matters. In the end, the Federal Reserve's actions on interest rates have both positive and negative effects-both micro- and macro- issues must be included when formulating policy in order to achieve success in the U.S. economy.

\footnotetext{
${ }^{51}$ Mishkin,F., Eakins,S., “Financial Markets \& Institutions”, $5^{\text {th }}$ edition, Pearson (2006), p168

${ }^{52}$ Mishkin,F., Eakins,S., "Financial Markets \& Institutions”, $5^{\text {th }}$ edition, Pearson (2006), p168

${ }^{53}$ Eisenberg, David. “Greenspans’s Deficits.” Time, May 2, 2005. p. 44

${ }^{54}$ McLean, V. “Give the Economy a Break.” USA Today. September 22, 2004, A19.
} 
The Fed is one of the most prestigious institutions in the world. In fact it is not by pure accident that after the terrorist attack on the world trade center in September 2001, an institution like the Fed, within few hours of the attack, can make the following announcement: "The Federal Reserve System is open and operating" 55 . This message of the Fed to the financial system as a whole was clear: "We are here" and has directly been translated into real actions. The Fed provided $\$ 45$ billion to banks through the discount window; two hundred times more than the amount provided the week before.

Greenspan's Fed was to hold rates at 1 per cent from 2003 to June 2004, long after the dotcom bubble was over. It is clear that monetary policy was too accommodative. Rates of 1 per cent were bound to encourage all kinds of risky behaviour. Greenspan's book ${ }^{56}$ tried to clear his name by blaming the bubble on an Asian savings glut, which purportedly created stimulus beyond the control of the Fed by driving down global bond rates.

The Federal Reserve and Greenspan's ${ }^{57}$ leadership of it does bear part of the blame for the subprime collapse and the wider damage to which it has led. As is becoming ever more apparent, many of the lending practices in the mortgage market during these years, especially in the subprime market, involved carelessness, deception, or both. Many people borrowed who had no prospect of servicing the loans they took out; they were hoping either to resell the house at a higher price, or to refinance it and draw on the appreciated value to make their payments. Some borrowers were apparently induced to buy houses they could not afford, or to take out loans they should not have been granted, by irresponsible brokers and other agents keen to make commissions on transactions despite knowing they were inappropriate.

\footnotetext{
${ }^{55}$ Mishkin,F., Eakins,S., “Financial Markets \& Institutions”, $5^{\text {th }}$ edition, Pearson (2006), p189

${ }^{56}$ Greenspan, A., "The Age of Turbulence: Adventures in a New World”, Penguin, 2007

${ }^{57}$ Greenspan, A., “The Age of Turbulence: Adventures in a New World”, Penguin, 2007
} 
Many of the banks that packaged these loans into securities also put them into complex investment "vehicles" that they did not understand, and sold them to investors who understood even less about them. The credit rating agencies, on which investors normally rely to inform them of such risks, were at best useless. Today the wreckage, consisting of abandoned houses, defaulted loans, displaced homeowners, banks making good on the billions of dollars of losses they had guaranteed, and uninsured investors marking down their portfolios, can be seen everywhere.

With respect to the housing bubble, the Fed asserts its innocence. It says that monetary policy was appropriate. It also takes the position that while, ex post, it is clear that supervision and regulation was too lax, no one saw the housing and credit bubble forming. Consequently, they cannot be blamed.

The assertion that the stance of monetary policy was appropriate given the measured inflation rate just assumes away the problem. If policy contributed to the bubble, then it was inappropriate regardless of the inflation rate. Contrary to the Fed position, people did see the housing and credit bubbles forming, although they were in the minority. Most importantly, the Fed as the central bank and the principle banking regulator alone had the responsibility of forestalling systemic risks. Even if no one else saw the bubble forming, the Fed should have. Saying no one else saw the crisis brewing is no defence.

\section{The Power of Wall Street}

The U.S. is now suffering from the aftershock of the irresponsible policies of Alan Greenspan. By keeping rates too low for too long following the terrorist attacks of 2001 and the dotcom crash, Ben Bernanke's iconic predecessor may have pleased his political masters, but he also pumped up America's gigantic real estate bubble. 
The Fed now needs to be able to explain why what is good for Wall Street is also good for the economy as a whole. The Fed listened to Wall Street and believed what it heard, or at any rate, acted as if it believed. Wall Street tells the Fed about its pain, what its pain means for the economy at large and what the Fed ought to do about it. Wall Street's pain was indeed great - deservedly so in most cases. Wall Street engaged in special pleading by exaggerating the impact on the wider economy of the rapid deleveraging that was taking place. Wall Street wanted large rate cuts fast so as to improve its solvency, not its liquidity, and Wall Street wanted the provision of ample liquidity against overvalued collateral. Why did Wall Street get what it wanted?

Throughout the crisis, it is difficult to avoid the impression that the Fed is too close to the financial markets and leading financial institutions, and too responsive to their special pleadings, to make the right decisions for the economy as a whole. Historically, the same behaviour has characterised the Greenspan Fed. The Bernanke Fed like the Greenspan Fed displays the same excess sensitivity to Wall Street concerns.

\section{Conclusion}

There is little room for doubt, that the Fed under Greenspan treated the stability, wellbeing and profitability of the financial sector as an objective in its own right, regardless of whether this contributed to the Fed's legal triple mandate of maximum employment, stable prices and moderate long-term interest rates. While the Bernanke Fed has but a short track record, its rather panicky reactions and actions since August 2007 suggest that it too may have a distorted and exaggerated view of the importance of the financial sector for macroeconomic stability. Ben Bernanke's initial four-year term expires next year. President Barack Obama may not reappoint him as his performance has not been impressive. The options are limited for a qualified successor with Former Clinton Treasury Secretary Robert Rubin’s reputation in tatters. Robert Rubin’s Citibank letter of resignation admitted despite his long experience in the financial services industry he did not recognise the serious possibility of the extreme circumstances that led to the financial system breakdown. Larry Summers has a record in helping sponsor the financial 
deregulation that helped contribute to the current financial meltdown. As Clinton Treasury Secretary after Rubin for example, he joined Alan Greenspan and Robert Rubin in heading off attempts to regulate the derivatives market. Overexposure to credit derivatives of mortgage-backed securities was a key reason for the failure of US financial institutions Bear Stearns, Lehman Brothers, Merrill Lynch, American International Group, and Washington Mutual in 2008.

The Federal Reserve has been dominated recently by academics who are prisoners of the Efficient Market Hypothesis that assumes man acts rationally and efficiently in economic matters in ways that can be caught in elegant mathematical models. Ben Bernanke, chairman of the Federal Reserve, shares this view completely, and Alan Greenspan, his predecessor, when it suited him. In such a convenient world, there can be no bubbles and no crashes.

The Fed must show some backbone. If you always take the friendly way out, no bubbles will ever be pricked and we shall always be reacting to crises in an increasingly speculative world. Paul Volcker, the Fed chairman before Alan Greenspan, had the character to do tough, unpleasant things where necessary. Paul Volcker was sacked for implementing unpleasant but necessary policies. Greenspan and Bernanke in contrast have not been able make the hard decisions. There is a need for President Obama to stop appointing as Fed chairmen either academic economists - out of touch with the messy real world (Bernanke) or mediocre commercial economists (Greenspan) and find someone with solid banking experience. 